\title{
築谷康人 学位論文審査要旨
}

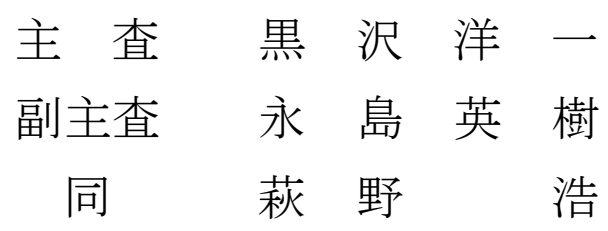

\section{主論文}

Epidemiology of fragility fractures in Sakaiminato, Japan: incidence, secular trends, and prognosis

（境港市における脆弱性骨折の疫学について：発生率、近年の傾向、予後）

(著者 : 築谷康人、萩野浩、伊藤靖代、永島英樹)

平成27年 Osteoporosis International DOI : 10.1007/s00198-015-3124-z

\section{参考論文}

1. 右尺骨骨折の治療に工夫を要した先天性無痛無汗症の1例

（著者：築谷康人、岡野徹、山下優嗣、豊島良太）

平成25年 整形外科と災害外科 62 巻 66 頁〜 71頁

2. Oblong Cupを用いた寛骨臼側置換術の長期成績

(著者 : 築谷康人、岡野徹、岸本勇二、豊島良太)

平成 25 年 日本人工関節学会誌 43巻 359頁～360頁 


\section{学位 論文要 旨}

Epidemiology of fragility fractures in Sakaiminato, Japan: incidence, secular trends, and prognosis

\section{（境港市における脆弱性骨折の疫学について：発生率、近年の傾向、予後）}

脆弱性骨折は活動性の制限、寝たきり、さらには生命予後にも影響を与えることから、 高齢者社会の日本において大きな社会問題となっておりその対策が急務である。一方、骨 折部位別の発生率や骨折原因については必ずしも充分な調査結果が得られているものでは なく、今後の予防対策を考える上で現在の骨折患者の実態を明らかにする必要がある。本 研究では、医療機関を受診した脆弱性骨折患者の実態調査を行い、今後の骨折予防、健康 寿命の延伸対策立案に役立てることを目的とした。

\section{方 法}

境港市内およびその周辺の整形外科を標榜する病院および診療所10施設を対象として、 2010年1月1日から2012年12月31日の3年間に受診した骨折患者を調査した。大腿骨近位部骨 折、上腕骨近位端骨折、橈骨遠位端骨折、臨床春椎椎体骨折患者を対象とし、それぞれ患 者数、発生頻度（年齢階級別発生率）、骨折受傷時における患者背景について調査した。 また、対象施設のうちの2施設において、受傷後1年の時点での予後および治療状況につい て調査した。年齢が50歳未満の患者、鳥取県境港市以外に居住する患者、腫瘍による病的 骨折患者は除外した。四肢骨骨折の診断はすべてX線像で行った。臨床脊椎椎体骨折に関し ては、X線像と身体所見に基づき整形外科医が診断した患者を対象とし、必要に応じてMRI での評価を行った。既存骨折や陳旧性骨折は対象から除外した。境港市の人口に基づき性・ 年齢調整発生率をそれぞれ算出し、過去の発生率や他地域の発生率と比較した。発生率の 経年的推移を比較・検討する際には、ポアソン近似法を用いて統計学的検討を行った。

\section{結 果}

2010年から 2012 年の発生率（10万人・年当たり）は、男女それぞれ、大腿骨近位部骨折 が217、567、上腕骨近位端骨折が26、96、橈骨遠位端骨折が82、432、臨床春椎椎体骨折が 412、1229であった。境港市における四肢骨骨折の発生率は、1990年代の発生率と比較して 有意に上昇していた。全体の35\%の患者に脆弱性骨折の既往を認めており、同じ部位の骨 
折の既往歷（反対側も含む）がある患者は、大腿骨近位部骨折で $34 \%$ 、上腕骨近位端骨折 で0\%、橈骨遠位端骨折で $12 \%$ 、臨床脊椎椎体骨折で76\%であった。骨粗鬆症の治療を受け ていた患者は、大腿骨近位部骨折で16\%、上腕骨近位端骨折で $15 \%$ 、橈骨遠位端骨折で $9 \%$ 、 臨床脊椎椎体骨折で18\%であった。脆弱性骨折の既往がある患者で、骨粗鬆症の治療を受 けていたのは $31 \%$ であった。受傷後 1 年の時点で追跡調査が可能であったのは、 516 人中 297 人 $(58 \%)$ であった。1年後の生存率は $91 \%$ であり、受傷後 1 年以内における二次性骨折の 発生率は $19 \%$ であった。1年後に骨粗鬆症の治療を受けていた患者は全体の $37 \%$ あ゙あ、そ のうちの65\%が今回の骨折受傷後に骨粗鬆症の治療を開始されていた。

\section{考 察}

これまでの報告と同様に、境港市における四肢骨骨折の発生率は北欧諸国と比較して低 いものであったが、経年的にはいまだ上昇傾向にあった。欧米諸国では、四肢骨骨折の発 生率は経年的に減少傾向となっている点を考慮すると、境港市において骨粗鬆症に対する 治療が不十分であることが示唆される。しかし、2004年〜2006年の鳥取県における大腿骨 近位部骨折の発生率と比較してみると、女性では発生率に大きな差は認められなかった。 アジア諸国でも地域によっては大腿骨近位部骨折の発生率は 2000 年以降横ばいになってき ており、境港市でも今後の推移を検討する必要がある。臨床春椎椎体骨折について本研究 は日本で性・年齢調整発生率を算出した最初の報告となった。四肢骨骨折とは対照的に、 北欧諸国と比較してその発生率は高い結果であった。この結果は、過去の報告によると、 骨の大きさ、骨密度、生活様式、カルシウム摂取量などの違いが要因として考えられてい る。海外で調查された臨床脊椎椎体骨折の発生率は、形態学的骨折の約 3 分の1であると報 告されている。本研究結果で明らかとなった臨床春椎椎体骨折発生率は、過去に日本で調 查された形態学的骨折発生率のおよそ3分の 1 となっており、海外の報告と同様の結果であ った。骨粗鬆症の治療率および治療継続率はこれまでの国内外の報告と同様に低值であっ た。この結果からも、骨粗鬆症に対する適切な治療が十分に行われていない現状が示唆さ れた。

\section{結 論}

境港市における四肢骨脆弱性骨折の発生率は、1990年代の発生率と比較して有意に上昇 していた。臨床脊椎椎体骨折の発生率は、諸外国と比較して高值であった。骨折受傷前後 において、骨粗鬆症に対する治療率および治療継続率は低值であった。 